\title{
Reflecting on 100 Issues of the TIM Review
}

\author{
Chris McPhee
}

\author{
(6 The past empowers the present, and the") \\ sweeping footsteps leading to this present \\ mark the pathways to the future.
}

Mary Catherine Bateson

Writer and cultural anthropologist

\begin{abstract}
First launched in 2007, the Technology Innovation Management Review has now reached the milestone of 100 issues. This article looks back over these first 100 issues, the themes they covered, trends in authorship and readership, and future opportunities and challenges for the journal.
\end{abstract}

\section{Introduction}

Since July 2007, this journal has been publishing monthly issues intended to bring together diverse viewpoints - from academics, entrepreneurs, companies of all sizes, the public sector, the community sector, and others - to bridge the gap between theory and practice. Originally called the Open Source Business Resource, the journal was relaunched in October 2011 as the Technology Innovation Management Review (TIM Review). With the publication of the current issue, the journal has now reached the 100-issue milestone.

This article follows on from the earlier article, "Reflecting on Fifty Issues of the OSBR", which marked and explained the transition from the OSBR to the TIM Review (McPhee, 2011). From its origins as a means to explore the business side of open source, the journal's core topics began to evolve as open source became "a better-understood, mainstream tool for technology businesses" (McPhee, 2011). With a relaunch, new name, and newly developed publication platform, the journal broadened its scope to the issues and emerging trends relevant to launching and growing technology businesses. The subsequent 50 issues of the TIM Review have focused on the theories, strategies, and tools that help small and large technology companies succeed, with a particular focus on the topics of technology and global entrepreneurship in small and large companies.
This article reflects upon the journal's 100 issues, with particular emphasis on the 50 most recent issues that were published since October 2011. First, an overview of the journal provides additional context to understand the journal's past and future. Next, the first 100 issues of the TIM Review are examined in terms of their themes and popularity. Finally, the article discusses the journal's future opportunities and challenges that will be faced in the next 100 issues.

\section{About the TIM Review}

The TIM Review is a monthly, peer-reviewed journal published in association with the Technology Innovation Management (TIM) program (Box 1), an international graduate program at Carleton University in Ottawa, Canada. The journal seeks to cover globally relevant topics of interest to authors and readers from a variety of roles and backgrounds, including academics and practitioners. In particular, the TIM Review seeks to provide opportunities to explore and legitimize new ideas for solving practical problems in emerging domains relevant to technology companies and innovation management professionals.

To maximize real-world value, remove barriers to diversity, encourage widespread dissemination, and assure quality content, the journal has been designed with the following distinctive features: 


\title{
Reflecting on 100 Issues of the TIM Review
}

\author{
Chris McPhee
}

1. Lessons from theory and practice: Whether the contributed insights come from academia or industry, authors are encouraged to emphasize the managerial implications of their work. The intention is to help authors develop, define, and share principles based on lessons from theory and practice, so that they can contribute solutions to real-world technology innovation problems.

2. Open access with no author fees: The journal does not charge its readers or its authors. Although the journal faces an ongoing challenge with sustainable funding and sponsorship, this approach is designed to remove any barriers to contribution and dissemination.

3. Editorial support: The TIM Review offers a high level of editorial support in addition to feedback through the peer-review process to improve the contributions from authors. This support is provided to all authors, but it particularly intended to encourage contributions from practitioners (who may not write regularly in the style and format required by a journal) and authors from around the world (who may need additional help in expressing their insights in English).

Since 2011, the TIM Review website (timreview.ca) has welcomed more than half a million unique visitors, and it now receives over 27,000 unique visitors per month from around the world. The authors have predominantly come from the Americas (especially Canada, where the TIM Review is based) and Europe, but the readers have been more evenly distributed (Figure 1). These trends are also reflected in the lists of the top 10 countries by authorship and readership (Table 1). However, the most recent data shows a trend toward even greater international representation. With regards to authorship, 2015 is the first year in which Canada did not have the highest percentage: more than half of the authors who have published in the TIM Review so far in 2015 are from Europe. Similarly, in 2015, readers from Asia (32\%) have so far overtaken readers from the journal's "home continent", the Americas (30\%).

In the 100 issues, the journal has published contributions from more than 650 authors in the form of 507 articles, 35 shorter and less formal "Q\&As" that provide answers to specific questions, and 39 summaries of lectures from the TIM Lecture Series at Carleton University. Each of these formats is open to both academic and practitioner contributions: the intention is to encourage a common platform for readers and authors, regardless of their role.

\section{Box 1. About the TIM Program}

The Technology Innovation Management program (TIM; timprogram.ca) is a Master's level program at Carleton University in Ottawa, Canada. It leads to either a Master of Applied Science (MASc) or a Master of Engineering (MEng) degree. All classes are offered in a traditional, face-to-face university setting; however, a distinctive feature of the TIM program is that all courses are also delivered concurrently over the Internet.

The objective of this program is to train aspiring entrepreneurs on creating wealth at the early stages of company or opportunity lifecycles. The program benefits are targeted at the following people:

- Founders of new companies

- People seeking more senior leadership roles within established companies

- Talented professionals building credentials and expertise for their next career move

- People who wish to work for or supply specialized services to founders of new companies or new lines of business of existing companies

- People who wish to improve the health of ecosystems that support technology entrepreneurship

The TIM program ecosystem includes Lead To Win (leadtowin.ca): an award-winning entrepreneurship community that provides coaching, early-buyer support, IT support, funding for students and young entrepreneurs, and development events. In 2015, Lead To Win was ranked by Stockholm-based UBI Global as one of the top 10 university business incubators in North America (Murray, 2015).

However, the shift in scope from the OSBR to the TIM Review was accompanied by a more academic article format and more rigorous peer review process, and there has been a corresponding shift toward more academic authors in the TIM Review, with PhD-level academics and students together accounting for $58 \%$ of TIM Review authors compared to $36 \%$ of OSBR authors (Figure 2). Nonetheless, the relative volume of practitioner contributions (i.e., articles by authors from the 


\section{Reflecting on 100 Issues of the TIM Review}

\section{Chris McPhee}
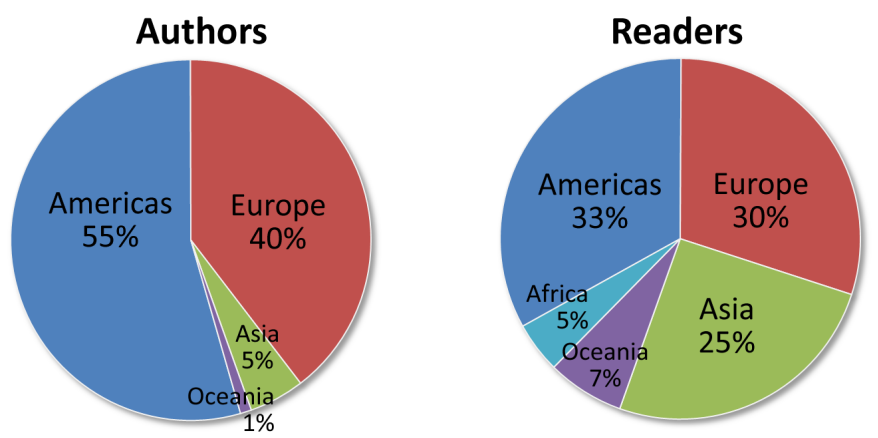

Figure 1. Geographical distribution of TIM Review authors and readers (2011 to 2015)
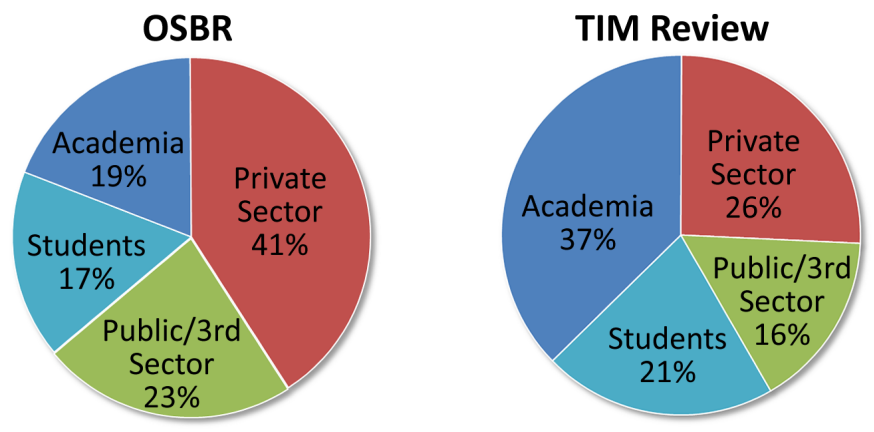

Figure 2. The diversity of author roles in the OSBR (2007-2011) and TIM Review (2011-2015)

private, public, and third/community sectors) has still accounted for $42 \%$ of TIM Review authors, suggesting that the journal remains an attractive publication to practitioner authors.

\section{Issue Themes and Popularity}

The majority of issues have covered particular editorial themes, such as technology entrepreneurship, open source business, and cybersecurity, which each have been covered in at least seven issues. Themes that have been covered in at least three issues include business ecosystems, living labs, service innovation, open innovation, and co-creation. A full list of themes from the 100 issues is presented in Appendix 1 and is available online in the issue archive (timreview.ca/issue-archive/).

Table 1 lists the 10 most popular TIM Review issues published since October 2011. In some cases, popularity reflects general interest across the articles in an issue; however, in other cases, there can be one or two highly popular articles that drive the popularity of the issue overall, as reflected in Table 1. Note that this list is

based on absolute web traffic and does not take into account the amount of time each article has been available online: newer issues may ultimately prove more popular once they have had more time to attract visits. Indeed, several issues published under the OSBR banner (i.e., before October 2011) have remained popular, including Co-Creation (December 2009 and March 2011), Economic Development (November 2010), Sales Strategy (October 2010), Growing Business (June 2010), and Technology Entrepreneurship (June 2011).

\section{Conclusion: Looking Ahead}

With the first 100 issues now published, the journal has reached a state of maturity where the challenges and opportunities are particularly exciting. In particular, we aim to grow the journal's reputation among the academic community. The journal is currently listed in the Directory of Open Access Journals (DOAJ), EBSCOhost, the Finnish Publication Forum (Julkaisufoorumi), Google Scholar, ProQuest, and Ulrich's, and we intend for this list to grow as the journal matures further. A key sign of progress will be for the journal to achieve recog- 


\section{Reflecting on 100 Issues of the TIM Review}

\section{Chris McPhee}

Table 1. Top 10 most popular* issues of the TIM Review published since October 2011

\begin{tabular}{|c|c|c|c|c|}
\hline & Issue & Theme & Guest Editor(s) & Driving Article(s) $)^{* *}$ \\
\hline 1 & Feb 2012 & $\begin{array}{l}\text { Technology } \\
\text { Entrepreneurship }\end{array}$ & Tony Bailetti & $\begin{array}{l}\text { - Q\&A. What Is Customer Value and How Do You Deliver } \\
\text { It? (Shanker, 2012a) }\end{array}$ \\
\hline 2 & Mar 2012 & $\begin{array}{l}\text { Technology } \\
\text { Entrepreneurship }\end{array}$ & Tony Bailetti & $\begin{array}{l}\text { - Global from the Start: The Characteristics of Born- } \\
\text { Global Firms in the Technology Sector (Tanev, 2012) } \\
\text { - A Customer Value Creation Framework for Businesses } \\
\text { That Generate Revenue with Open Source Software. } \\
\text { (Shanker, 2012b) }\end{array}$ \\
\hline 3 & Jun 2012 & Global Business Creation & $\begin{array}{l}\text { Marko Seppä \& } \\
\text { Stoyan Tanev }\end{array}$ & $\begin{array}{l}\text { - Building Trust in High-Performing Teams (Hakanen \& } \\
\text { Soudunsaari, 2012) }\end{array}$ \\
\hline 4 & Oct 2011 & $\begin{array}{l}\text { Introducing the TIM } \\
\text { Review }\end{array}$ & -- & $\begin{array}{l}\text { - Acquisition Integration Models: How Large Companies } \\
\text { Successfully Integrate Startups (Carbone, 2011) } \\
\text { - A Sales Execution Strategy Guide for Technology } \\
\text { Startups (Gilbert \& Davies, 2011) }\end{array}$ \\
\hline 5 & Sep 2012 & Living Labs & $\begin{array}{l}\text { Mika Westerlund \& } \\
\text { Seppo Leminen }\end{array}$ & -- \\
\hline 6 & Aug 2012 & $\begin{array}{l}\text { Entrepreneurship in the } \\
\text { 21st Century }\end{array}$ & -- & $\begin{array}{l}\text { - Creativity: Linking Theory and Practice for } \\
\text { Entrepreneurs (Duxbury, 2012) }\end{array}$ \\
\hline 7 & Aug 2014 & $\begin{array}{l}\text { Innovation and } \\
\text { Entrepreneurship in India }\end{array}$ & Kalyan Kumar Guin & $\begin{array}{l}\text { - The Government of India's Role in Promoting } \\
\text { Innovation through Policy Initiatives for } \\
\text { Entrepreneurship Development (Abhyankar, 2014) }\end{array}$ \\
\hline 8 & Dec 2012 & Recent Research & -- & $\begin{array}{l}\text { - Neuromarketing: Understanding Customers' } \\
\text { Subconscious Responses to Marketing (Suomala et al., } \\
\text { 2012) }\end{array}$ \\
\hline 9 & Feb 2013 & $\begin{array}{l}\text { Platforms, Communities, } \\
\text { and Business Ecosystems }\end{array}$ & Steven Muegge & $\begin{array}{l}\text { - Key Factors Affecting a Technology Entrepreneur's } \\
\text { Choice of Incubator or Accelerator (Isabelle, 2013) }\end{array}$ \\
\hline 10 & Aug 2013 & Cybersecurity & Tony Bailetti & -- \\
\hline
\end{tabular}

*Based on pageviews at timreview.ca from October 1, 2011 to October 31, 2015.

**Driving articles are articles that account for more than $1 / 3$ of an issue's pageviews. 


\section{Reflecting on 100 Issues of the TIM Review}

\section{Chris McPhee}

nition in lists of quality journals. The challenge will be to further increase the academic quality of the articles while maintaining the journal's status as a desirable publication for practitioner authors and readers.

While we seek to further solidify the TIM Review's increasing popularity and worldwide reputation, we must also work hard to ensure financial sustainability, which remains an ever-present challenge for any open-access journal, especially one that does not charge author fees. In addition to future experiments with business models that support the journal's global presence, an ongoing strategy to financially support the operations of the journal comes through "Best of TIM Review" book series, which has four published titles that are currently available through Amazon:

\section{For Technology Entrepreneurs (Bailetti \& Hurley, 2013)}

2. Business Models for Entrepreneurs and Startups (Muegge \& Haw, 2013)

3. Value Co-Creation (Tanev \& Seppä, 2013)

4. Cybersecurity (Craigen \& Gedeon, 2015)

Soon, additional "Best of TIM Review" books will be published on Living Labs and Open Source Business, in addition to a book that includes the most popular articles published in the TIM Review.

In terms of the next wave of articles that will hopefully become the "best of" the next 100 issues, our near-term editorial calendar includes familiar topics such as technology entrepreneurship, living labs, cybersecurity, and innovation management. However, we will continue to look ahead to domains where theory and practice may be limited, as evidenced by the authors in this 100th issue looking ahead and identifying the key unanswered questions in emerging domains. Our guest editors, authors, readers, and board members have played critical roles in identifying real-world problems that need research-based solutions, and we invite you to propose issue themes and article topics that will be developed, disseminated, and debated in future issues of the TIM Review.

\section{Acknowledgements}

As we look forward to the next 100 issues, I wish to express my gratitude to the more than half a million readers; the more than 650 authors; the dozens of guest editors, key contributors, and board members; the many anonymous but much appreciated reviewers; the OSBR's first Editor-in-Chief: Dru Lavigne; the Director of the TIM program: Tony Bailetti; the TIM program's faculty and technical and administrative staff; and the generous sponsors, all of whom have contributed in various important ways to the success of the journal's first 100 issues.

\begin{abstract}
About the Author
Chris McPhee is Editor-in-Chief of the Technology Innovation Management Review. Chris holds an MASc degree in Technology Innovation Management from Carleton University in Ottawa, Canada, and $\mathrm{BScH}$ and MSc degrees in Biology from Queen's University in Kingston, Canada. He has over 15 years of management, design, and content-development experience in Canada and Scotland, primarily in the science, health, and education sectors. As an advisor and editor, he helps entrepreneurs, executives, and researchers develop and express their ideas.
\end{abstract}




\section{Reflecting on 100 Issues of the TIM Review}

\section{Chris McPhee}

Appendix 1. 100 Issues of the TIM Review and OSBR (Available at timreview.ca/issue-archive/)

\begin{tabular}{|c|c|c|c|c|c|}
\hline & \multicolumn{5}{|c|}{ Technology Innovation Management Review } \\
\hline & 2011 & 2012 & 2013 & 2014 & 2015 \\
\hline January & & Open Source Business & $\begin{array}{l}\text { Open Source } \\
\text { Sustainability }\end{array}$ & Open Source Business & Cybersecurity \\
\hline February & & $\begin{array}{l}\text { Technology } \\
\text { Entrepreneurship }\end{array}$ & $\begin{array}{l}\text { Platforms, Communities, } \\
\text { and Business Ecosystems }\end{array}$ & Seeking Solutions & $\begin{array}{l}\text { Technology in Service } \\
\text { Innovation }\end{array}$ \\
\hline March & & $\begin{array}{l}\text { Technology } \\
\text { Entrepreneurship }\end{array}$ & Local Open Innovation & Emerging Technologies & $\begin{array}{l}\text { Innovation Tools and } \\
\text { Techniques }\end{array}$ \\
\hline April & & $\begin{array}{l}\text { Technology } \\
\text { Entrepreneurship }\end{array}$ & $\begin{array}{l}\text { Open Innovation and } \\
\text { Entrepreneurship }\end{array}$ & Service and Innovation & $\begin{array}{l}\text { Cyber-Resilience in } \\
\text { Supply Chains }\end{array}$ \\
\hline May & & $\begin{array}{l}\text { Technology } \\
\text { Entrepreneurship }\end{array}$ & Technology Evolution & Service and Innovation & Insights \\
\hline June & & Global Business Creation & Insights & $\begin{array}{l}\text { Opportunities and } \\
\text { Capabilities }\end{array}$ & $\begin{array}{l}\text { Critical Infrastructures } \\
\text { and Cybersecurity }\end{array}$ \\
\hline July & & Social Innovation & Cybersecurity & Insights & Creativity in Innovation \\
\hline August & & $\begin{array}{l}\text { Entrepreneurship in the } \\
\text { 21st Century }\end{array}$ & Cybersecurity & $\begin{array}{l}\text { Innovation and } \\
\text { Entrepreneurship in } \\
\text { India }\end{array}$ & Insights \\
\hline September & & Living Labs & $\begin{array}{l}\text { Managing Innovation for } \\
\text { Tangible Performance }\end{array}$ & Insights & Insights \\
\hline October & $\begin{array}{l}\text { Introducing the TIM } \\
\text { Review }\end{array}$ & Born Global & $\begin{array}{l}\text { Managing Innovation for } \\
\text { Tangible Performance }\end{array}$ & Cybersecurity & Smart Cities and Regions \\
\hline November & Recent Research & Insights & Living Labs & Cybersecurity & 100th Issue \\
\hline December & $\begin{array}{l}\text { Intellectual Property } \\
\text { Rights }\end{array}$ & Recent Research & $\begin{array}{l}\text { Living Labs and } \\
\text { Crowdsourcing }\end{array}$ & $\begin{array}{l}\text { Innovation and } \\
\text { Entrepreneurship }\end{array}$ & \\
\hline
\end{tabular}

\begin{tabular}{|c|c|c|c|c|c|}
\hline & \multicolumn{5}{|c|}{ Open Source Business Resource } \\
\hline & 2007 & 2008 & 2009 & 2010 & 2011 \\
\hline January & & Interoperability & Enterprise Participation & Success Factors & $\begin{array}{l}\text { The Business of Open } \\
\text { Source }\end{array}$ \\
\hline February & & Open Data & Commercialization & Startups & Recent Research \\
\hline March & & Procurement & Geospatial & Mobile & Co-Creation \\
\hline April & & Communications & Open APIs & Cloud Services & Collectives \\
\hline May & & Enterprise Readiness & $\begin{array}{l}\text { Open Source in } \\
\text { Government }\end{array}$ & $\begin{array}{l}\text { Communications } \\
\text { Enabled Applications }\end{array}$ & $\begin{array}{l}\text { Technology } \\
\text { Entrepreneurship }\end{array}$ \\
\hline June & & Security & Women in Open Source & Growing Business & $\begin{array}{l}\text { Technology } \\
\text { Entrepreneurship }\end{array}$ \\
\hline July & Introducing the OSBR & Accessibility & Collaboration & Go To Market & Women Entrepreneurs \\
\hline August & Business Models & Education & Tech Entrepreneurship & Interdisciplinary Lessons & Miscellany \\
\hline September & Defining Open Source & Social Innovation & Business Intelligence & Keystone Companies & \\
\hline October & Licensing & Building Community & Arts \& Media & Sales Strategy & \\
\hline November & Support & Health and Life Sciences & Value Co-creation & Economic Development & \\
\hline December & $\begin{array}{l}\text { Clean Intellectual } \\
\text { Property }\end{array}$ & Enabling Innovation & Value Co-Creation & $\begin{array}{l}\text { Humanitarian Open } \\
\text { Source }\end{array}$ & \\
\hline
\end{tabular}




\section{Reflecting on 100 Issues of the TIM Review}

\section{Chris McPhee}

\section{References}

Abhyankar, R. 2014. The Government of India's Role in Promoting Innovation through Policy Initiatives for Entrepreneurship Development. Technology Innovation Management Review, 4(8): $11-17$.

http://timreview.ca/article/818

Bailetti, T., \& Hurley, B. 2013. Best of TIM Review: For Technology Entrepreneurs. Ottawa: Talent First Network (Carleton University). http://amazon.com/dp/B00BM670AY/

Carbone, P. 2011. Acquisition Integration Models: How Large Companies Successfully Integrate Startups. Technology Innovation Management Review, 1(1): 36-31. http://timreview.ca/article/490

Craigen, D., \& Gedeon, I. 2015. Best of TIM Review: Cybersecurity. Ottawa: Talent First Network (Carleton University). http://amazon.com/dp/B00XD3O6L0/

Duxbury, T. 2012. Creativity: Linking Theory and Practice for Entrepreneurs. Technology Innovation Management Review, 2(8): $10-15$. http://timreview.ca/article/594

Gilbert, I., \& Davies, S. 2011. A Sales Execution Strategy Guide for Technology Startups. Technology Innovation Management Review, 1(1): 32-36.

http://timreview.ca/article/491

Hakanen, M., \& Soudunsaari, A. 2012. Building Trust in HighPerforming Teams. Technology Innovation Management Review, 2(6): 38-41.

http://timreview.ca/article/567

Isabelle, D. A. 2013. Key Factors Affecting a Technology Entrepreneur's Choice of Incubator or Accelerator. Technology Innovation Management Review, 3(2): 16-22. http://timreview.ca/article/656
McPhee, C. 2011. Reflecting on Fifty Issues of the OSBR. Open Source Business Resource, August 2011: 32-36.

http://timreview.ca/article/465

Muegge, S., \& Haw, C. 2013. Best of TIM Review: Business Models for Entrepreneurs and Startups. Ottawa: Talent First Network (Carleton University). http://amazon.com/dp/B00ESLVCRW/

Murray, A. 2015. Global Insights: Celebrating the Future of Academic Incubators - UBI Awards in North America. UBI Global, Press Release, November 4, 2015. Accessed November 4, 2015: http://ubi-global.com/global-insights-celebrating-the-future-ofacademic-incubators-ubi-awards-in-north-america/

Shanker, A. 2012a. Q\&A. What Is Customer Value and How Do You Deliver It? Technology Innovation Management Review, 2(2): 32-33.

http://timreview.ca/article/525

Shanker, A. 2012b. A Customer Value Creation Framework for Businesses That Generate Revenue with Open Source Software. Technology Innovation Management Review, 2(3): 18-22. http://timreview.ca/article/534

Suomala, J., Palokangas, L., Leminen, S., Westerlund, M., Heinonen, J., \& Numminen, J. 2012. Neuromarketing: Understanding Customers' Subconscious Responses to Marketing. Technology Innovation Management Review, 2(12): 12-21. http://timreview.ca/article/634

Tanev, S. 2012. Global from the Start: The Characteristics of BornGlobal Firms in the Technology Sector. Technology Innovation Management Review, 2(3): 5-8. http://timreview.ca/article/532

Tanev, S., \& Seppä, M. 2013. Best of TIM Review: Value Co-Creation. Ottawa: Talent First Network (Carleton University). http://amazon.com/dp/B00GR7BXJ2/

Keywords: Technology Innovation Management Review, TIM Review, Open Source Business Resource, OSBR, journal, innovation, entrepreneurship, management, technology, business 